Goldschmidt 2021 Abstract

https://doi.org/10.7185/gold2021.4186

\section{Genesis of the Florida Canyon Nonsulfide Zn(-Pb) ores (Northern Peru): new insights on mineralizing events in the Bongará district}

\author{
RITA CHIRICO ${ }^{1}$, NICOLA MONDILLO ${ }^{2}$, MAURIZIO \\ AMBROSINO $^{3}$, MARIA BONI ${ }^{4}$, GIUSEPPINA \\ BALASSONE $^{5}$, MICHAEL JOACHIMSKI ${ }^{6}$, ANGELA \\ MORMONE $^{7}$ AND YANNICK BURET ${ }^{8}$ \\ ${ }^{1}$ Università degli studi di Napoli \\ ${ }^{2}$ Dipartimento di Scienze della Terra, dell'Ambiente e delle \\ Risorse Università degli Studi di Napoli \\ ${ }^{3}$ Università degli studi del Sannio \\ ${ }^{4}$ Dept. Scienze della Terra, dell'Ambiente e delle Risorse \\ University of Napoli Federico II \\ ${ }^{5}$ Università di Napoli Federico II \\ ${ }^{6}$ University of Erlangen-Nuremberg \\ ${ }^{7}$ Istituto Nazionale di Geofisica e Vulcanologia \\ ${ }^{8}$ Natural History Museum \\ Presenting Author: rita.chirico@unina.it
}

Florida Canyon is a carbonate-hosted $\mathrm{Zn}(-\mathrm{Pb})$ mixed sulfidenonsulfide deposit (Nexa Resources Peru), located in the Subandean fold-and-thrust belt of Northern Peru (Bongará Province), with total resources of 12.1 million tons at a grade of $10.7 \% \mathrm{Zn}$ and $1.2 \% \mathrm{~Pb}$ [1]. The nonsulfide mineralization, hosted by the dolomitized carbonates of the Chambará Formation (Pucará Group), has a very complex distribution developed up to hundreds of meters in depth. These secondary ores are characterized by a great variety of textures and mineral associations. Two distinct nonsulfide facies have been observed: (1) group 1 - reddish-brown nonsulfide facies, in both smithsonite and hemimorphite-prevailing bodies, showing features and compositions suggesting direct replacement processes [2], generally only partly obliterating the primary sulfide ores, characterized by stratabound "mantos" or highangle bodies of sphalerite and galena [3]; (2) group 2 - white-togrey smithsonite, defined by grey colloform bands at the macroscale and highly crystalline textures at the micro-scale, likely derived from wall rock replacement [2].

The wide range of the $\mathrm{C}-\mathrm{O}$ stable isotopes compositions suggests that the genesis of the Florida Canyon mineralization was related to the supergene processes, characterized by percolation of meteoric waters in a deep hydrological "open system" in a humid tropical environment, characterized by complex dynamics of the circulating fluids and different recharge origins and processes, resulting in variable oxidizing water chemistry and non-equilibrium fractionation processes.

Through LA-ICP-MS analyses, high Ge concentrations were observed in hemimorphite and Fe-hydroxides (average 57 and $738 \mathrm{ppm}$ Ge, respectively). These results, together with the bulkrock Ge concentrations (up to $216 \mathrm{ppm}$ ) in hemimorphite- and goethite-rich samples, which are close to the bulk Ge contents exhibited by sphalerite-bearing samples (mean 168 ppm), suggest that during weathering Ge was retained in secondary phases directly forming at the sphalerite expenses [4].

[1] SRK Consulting (2017), SRK Consulting (U.S.), Inc., Nevada, USA, $145 \mathrm{p}$.

[2] Hitzman, Reynolds, Sangster, Allen and Carman (2003), Economic Geology 98, 685-714.

[3] de Oliveira, Leach, Juliani, Monteiro and Johnson (2019b), Economic Geology 114 n. 8, 1621-1647.

[4] Mondillo, Arfè, Herrington, Boni, Wilkinson and Mormone (2018)., Mineralium Deposita 53, 155-169. 